\title{
PENTADBIRAN UNDANG-UNDANG HARTA PUSAKA MUALAF DI MALAYSIA: SATU SOROTAN LITERATUR
}

\section{Administration of Mualaf Inheritance at Wilayah Persekutuan: A Literature Highlights}

\author{
Mohd Zainudin Wan Yusoff* \\ Luqman Hj Abdullah** \\ Nurulhuda Ahmad Zaki***
}

\begin{abstract}
Inheritance is something that has material value left by a person after his death which is obtained during his life truly and becomes the perfect property during his life and is eternally owned by simati until he dies. In Malaysia, the distribution of Islamic inheritance is subject to faraid law, in which non-Muslims cannot inherit Muslim property. However, for the property of non-Muslims, there is a law that protects it, namely
\end{abstract}

* Master Candidate, Department of Fiqh and Usul, Academy of Islamic Studies, University of Malaya, 50603, Kuala Lumpur. zainudinwanyusoff@gmail.com

** Senior Lecturer, Department of Fiqh and Usul, Academy of Islamic Studies, University of Malaya, 50603, Kuala Lumpur; Mufti, Pejabat Mufti Wilayah Persekutuan Jabatan Perdana Menteri, 62100 Putrajaya.luqmanabdullah@um.edu.my

*** Senior Lecturer, Department of Fiqh and Usul, Academy of Islamic Studies, University of Malaya, 50603, Kuala Lumpur. zafran@, um.edu.my 
the Distribution (Amendment) Act 1997, Act 1004. This Act does not state that Muslims cannot inherit the inheritance of non-Muslims. The distribution is made to the heirs based on the kinship relationship and marriage regardless of religion. This means that Muslims also inherit the property of non-Muslims. The two main methods of distributing inheritance that is practiced in Malaysia are the distribution method according to Islamic law for the death of a Muslim and the distribution method according to civil law which affects the Act of Dispensing 1958 (Act 300) for the death of non-Muslims. Both mechanisms involve converts, either converts as the dead or as heirs. Those with the title of convert to Islam have their uniqueness in the distribution of inheritance which is different from the usual inheritance distribution mechanism. Due to these differences in distribution, this study was carried out to highlight the administration of inheritance laws involving converts to Islam in Malaysia. This study was conducted using a qualitative method by taking a literature review approach, also continuing the content analysis design. The results of the study highlights that have been carried out show that there have been many writings, ideas, and discussions regarding this case made by the reviewers. The results of the study found that there are procedures and provisions for laws in the settlement of inheritance involving heirs of converts if they are not Muslim, as well as if converts are heirs to the property of the dead who are not Muslim. Therefore, with an explanation of the administration of the law in this study, it can resolve errors to the public regarding the issue of inheritance and property inheritance involving converts in Malaysia.

Keywords: inheritance, mualaf, heirs, inheritance law 


\section{PENDAHULUAN}

Persoalan mengenai pengurusan dan pentadbiran harta pusaka merupakan persoalan yang tidak akan lenyap selamanya memandangkan ianya berkait rapat dengan urusan seharian manusia. Kematian dan manusia tidak dapat dipisahkan. Selagi ada kematian dan si mati memiliki harta peninggalan sama ada Islam atau bukan Islam, maka selagi itulah tuntutan ke atasnya akan berlaku oleh waris si mati. Dalam konteks agama Islam, apabila seseorang Muslim meninggal dunia, harta yang ditinggalkan oleh si mati merupakan harta pusaka yang perlu diuruskan segera. Mengikut hukum Islam, harta yang ditinggalkan si mati perlu difaraidkan dan diuruskan pembahagiannya mengikut hukum Islam. Setiap ahli waris akan mempunyai hak tersendiri dalam harta si mati tersebut. Dalam konteks masyarakat, tidak semua ahli waris memahami dan mengetahui secara terperinci kaedah dan jumlah pembahagiannya. ${ }^{1}$

Oleh demikian, terdapat badan dan institusi yang ditubuhkan di Malaysia bertujuan menguruskan faraid tersebut. Namun apa yang merumitkan ialah apabila si mati dan waris berbeza agama. Timbul isu dan persoalan bagaimana jika si mati merupakan mualaf dan ahli warisnya ialah bukan Islam. Bagaimana pula sekiranya si mati bukan Islam sebaliknya waris adalah muslim. Dalam arus modenisasi masa kini, timbul pelbagai isu lain yang menambahkan kerumitan dalam pembahagian harta pusaka mualaf. Menurut statistik pada tahun 2006, dianggarkan lebih sejuta kes tuntutan harta pusaka di Malaysia dengan nilai mencecah RM 38 billion masih tertunggak serta tidak diuruskan oleh ahli waris. Keadaan

\footnotetext{
Beberapa kajian lepas tentang kefahaman masyarakat Islam setempat seperti di sekitar Lembah Klang dan Kuala Terengganu dijalankan mendapati tahap kefahaman masyarakat masih kurang dan sederhana. Lihat lanjut Noor Syahida Abdul Rahman, Hasliza Talib, Nurhayati Abd. Ghani, Nur Zulfah Md Abdul Salam \& Nurul Syafini Abd Rahman, "Pengurusan Tuntutan Harta Pusaka dalam Kalangan Masyarakat Islam: Kajian di Lembah Klang," Journal of Muwafaqat 1, no. 2 (2018), 96-117; Nurul Izzah Nokman \& Farahwahida Mohd Yusof, "Perspektif Masyarakat Muslim Terhadap Pengurusan Harta Pusaka di Kuala Terengganu," (Disertasi Sarjana, Universiti Teknologi Malaysia, 2012), 1.
} 
ini disebabkan oleh isu pentadbiran yang sukar diatasi disamping sikap masyarakat sendiri yang kurang berminat untuk merancang pengagihan harta sebelum mereka meninggal dunia. ${ }^{2}$ Oleh demikian, artikel ini akan menyoroti kedudukan perundangan dan pentadbiran harta pusaka mualaf di Malaysia. Ini boleh dijadikan panduan kepada ahli waris dalam tindakan mereka berkaitan harta mualaf seterusnya menyelesaikan permasalahan dan isu dihadapi ahli waris.

\section{KONSEP HARTA PUSAKA MUALAF}

\section{Mualaf dan Konflik Harta Pusaka Mualaf}

Mualaf ialah golongan yang baru memeluk Islam atau juga dikenali sebagai saudara baru dalam Islam. ${ }^{3}$ Dalam surah al-taubah, ayat ke 9, juzuk ke 60 turut menyentuh tentang istilah mualaf iaitu disebut sebagai "mu'allafah qulubuhum" yang merupakan salah satu golongan daripada lapan golongan dalam asnaf zakat. Menurut fiqh, kalimah mu'allafah qulubuhum ini bermaksud mereka yang baru memeluk Islam dan iman mereka masih lemah. Mereka ini layak diberikan zakat untuk menguatkan lagi pegangan mereka terhadap Islam. Ia terbuka kepada semua umat Islam tanpa ada batasan masa sama ada mereka masih baru memeluk Islam atau menganutinya semenjak awal lagi. ${ }^{4}$

Dalam konteks perundangan di Malaysia, takrif mualaf berbeza antara negeri. Ini kerana pentafsirannya mengikut peruntukan dalam Akta, Enakmen, atau Ordinan yang digunapakai. Sebagai contoh dalam Akta Pentadbiran Agama Islam Undang-Undang Islam (Wilayah-Wilayah Persekutuan) 1993 (Akta 505) di bawah tajuk Pengiktirafan Muallaf Sebagai Orang Islam ${ }^{5}$

2 Rusnadewi Abdul Rashid \& Noor Inayah Yaakub, "Masalah Kegagalan dan Kelewatan Pengagihan Harta Pusaka di Malaysia," Jurnal Intelek 5, no. 2 (2010).

3 Noresah Bahrom et al., Kamus Dewan, ed. 4 (Kuala Lumpur: Dewan Bahasa dan Pustaka, 2005), 1046.

4 M. Abdul Mujieb, Kamus Istilah Figh (Jakarta: PT Pustaka Firdaus, 1997), 221.

5 Seksyen 91(1), Akta Pentadbiran Undang-Undang Islam (WilayahWilayah Persekutuan) 1993. 
memperuntukkan mualaf adalah: "Seseorang yang telah masuk Islam dan telah didaftarkan dalam Daftar Muallaf hendaklah, bagi maksud mana-mana undang-undang persekutuan atau Negeri, dan untuk semua masa, diperlakukan sebagai seorang Islam. " Di luar sana pelbagai istilah yang diguna oleh masyarakat dan pihak berwajib dalam usaha mendekati golongan mualaf. Panggilan mesra yang sering didengar ialah saudara Muslim, atau saudara baru, saudara kita, saudara Islam dan sebagainya. Kesemua istilah ini membawa maksud yang sama, yang berbeza hanya istilah yang digunakan.

Di Malaysia jumlah mualaf menunjukkan peningkatan dari semasa ke semasa. Sehingga tahun 2012, jumlah mualaf direkodkan oleh Jabatan Kemajuan Islam Malaysia (JAKIM) seramai 106,747 orang. Seiring peningkatan bilangan mualaf, muncul pelbagai isu yang meruncing berkaitan mualaf bermula seawal mereka memeluk Islam sehinggalah selepas kematian mereka. Ini termasuk isu dan konflik berkaitan pewarisan atau pembahagian harta pusaka mualaf. ${ }^{6}$

Dalam pelaksanaan pembahagian harta pusaka yang melibatkan mualaf, undang-undang di Malaysia tidak memperuntukkannya secara khusus dalam statut pentadbiran Islam, tetapi secara umumnya ia adalah berdasarkan hukum syarak. Umumnya, pengurusan pembahagian harta pusaka melibatkan dua mekanisme iaitu hukum syarak iaitu faraid dan mekanisme undang-undang. Mekanisme undang-undang adalah merujuk kepada Akta Pembahagian 1958, di mana akta ini menjadi rujukan bagi menguruskan harta pusaka kematian yang melibatkan bukan Islam. Manakala mekanisme faraid adalah dirujuk bagi menyelesaikan pembahagian harta pusaka kematian orang Islam. Pengasingan mekanisme ini telah menimbul konflik kepada mualaf yang berada pada posisi pewaris iaitu apabila berlaku kematian waris bukan Islam.

Pengurusan dalam membahagi harta pusaka orang bukan Islam, apabila berlakunya kematian waris, pewaris seperti dinyatakan dalam Akta Pembahagian 1958 adalah ibu, bapa, suami, isteri,

$6 \quad$ Siti Adibah Abu Bakar \& Siti Zubaidah Ismail, "Pengurusan Mualaf di Malaysia: Kerjasama Dinamik Antara Agensi Kerajaan dan Bukan Kerajaan," Jurnal Usuluddin 46, no. 2 (2018), 98. 
anak dan zuriat atau keturunan yang ke bawah. Akta ini tidak mempunyai peruntukan yang menyatakan bahawa seorang Islam tidak boleh mewarisi harta simati yang bukan Islam ${ }^{7}$. Dengan ini, mengikut Akta Pembahagian 1958, mualaf tersebut akan menerima bahagian pusaka atas kematian ibu, bapa, suami, isteri, anak dan keturunan ke bawah yang bukan Islam. Ini bertentangan dengan hukum Islam bahawa orang Islam tidak boleh mewarisi harta pusaka orang bukan Islam. Ini dijelaskan dalam hadis berikut:

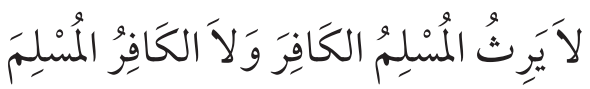

"Seorang muslim tidak boleh mewarisi harta seorang kafir, dan seorang kafir tidak boleh mewarisi harta seorang Muslim." 8

Di sini berlaku pertentangan dalam soal perwarisan harta antara penetapan syariat hukum Islam dengan undang-undang yang diamalkan di Malaysia khususnya undang-undang Akta Pembahagian 1958 yang diamalkan di Pejabat Pusaka Kecil bagi menguruskan harta pusaka bukan Islam. ${ }^{9}$ Penetapan prosedur dan undang-undang yang berbeza ini menimbulkan kekeliruan dalam kalangan masyarakat terutama mualaf untuk memilih kaedah yang tepat.

\section{Prinsip Pengurusan Harta Pusaka di Malaysia}

Harta Pusaka ditakrifkan sebagai harta yang ditinggal oleh seseorang yang mati untuk diwarisi oleh ahli keluarganya serta yang lain. Kamus Dewan mentakrifkan harta pusaka sebagai "segala

7 Norazura Sudin (Penolong Pengarah Kanan, Unit Pembahagian Pusaka Wilayah Persekutuan Kuala Lumpur), dalam temu bual beliau bersama penulis pada 24 Mei 2019.

8 Hadis riwayat al-Bukhari. Lihat Abū "Abd Allāh Muḥammad bin Ismā‘īl al-Bukhārī, "Șaḥị̣ al-Bukhārīi," dalam Mawsū 'at al-Hadīth al-Sharīf: al-Kutub al-Sittah, Șāih bin 'Abd al-'Azīz Āl al-Shaykh (ed.). Riyādh: Dār al-Salām, 2008), 565, "Kitāb al-Farāid, Bāb lā yarithu al-muslim al-kāfir wa lā la-kāfir al-muslim wa izā aslam qabl “an yuqsam al-mīrath falā mīrath lah," no. hadis 6764.

9 Nazli Zainal (Ketua Penolong Pengarah, Unit Pembahagian Pusaka Wilayah Persekutuan Kuala Lumpur), dalam temu bual beliau bersama penulis pada 27 Jun 2019. 
harta benda yang ditinggalkan oleh orang yang telah meninggal untuk diwarisi oleh keluarganya dan lain". ${ }^{10}$ Dalam Islam, harta Muslim yang ditinggalkan akan dibahagikan mengikut kaedah faraid. Perkataan faraid adalah jama' kepada faridhah iaitu kata terbitan daripada al-fardh. Dari segi istilah, ulama' mazhab Syafie berpendapat ilmu faraid bermaksud satu bahagian ahli waris yang telah ditentukan oleh syarak. ${ }^{11}$

Menurut ilmu faraid, harta pusaka turut dikenali sebagai altarikah yang bermaksud harta peninggalan ahli waris atau orang yang meninggal dunia. Namun dalam konsep al-tarikah, harta yang ditinggalkan kepada ahli waris adalah setelah dilakukan pemotongan wajib seperti membayar hutang si mati. ${ }^{12}$ Tarikah juga ditakrifkan sebagai perkara yang ditinggalkan oleh si mati sama ada harta benda dan kepentingan-kepentingan tertentu seperti hutang, gadaian dan sebagainya. ${ }^{13}$ Harta warisan disebut juga tarikah yang bermaksud peninggalan.

Menurut jumhur ulama' tarikah itu bukan saja harta benda, tetapi meliputi semua perkara yang ditinggalkan oleh si mati, sama ada hutang piutangnya, anak-anak, benda-benda yang dibuatnya dan lain-lain perkara yang ditanggungnya. ${ }^{14}$ Dalam menginterpretasi maksud tarikah, maka boleh disimpulkan tarikah merupakan harta peninggalan si mati yang telah bersih dari hutang dan wasiat serta ia akan diwarisi oleh waris-warisnya yang hidup. Takrif ini berdasarkan firman Allah SWT, dalam al-Quran:

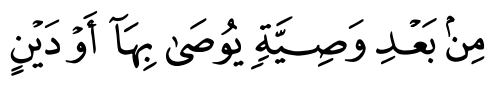

"Selepas menyelesaikan wasiat dan bayaran

10 Noresah Bahrom et al., Kamus Dewan, ed 3, cet. ke 2 (Kuala Lumpur: Dewan Bahasa dan Pustaka, 1996), 1074.

11 Al-Baghawī, Abū Muhammad al-Husayn bin Mas‘ūd, al-Tahẓīb fì Fiqh al-Imām al-Shāfi 'ì (Bayrūt: Dār al-Kutub al-'Ilmiyyah, t.t.), 5: 3.

12 Elviana Sagala, "Ketentuan Tentang Harta Peninggalan (Tarikah) dalam Hukum Islam,” Jurnal Ilmiah “Advokasi” 5, no. 1 (2017), 34.

13 Muhammad 'Alī al-Ṣābūnī, al-Mawārīth fì al-Sharī'ah al-Islāmiyyah fì Daw'i al-Kitāb wa al-Sunnah (Dimashq: Dār al-Qalam, 1989), 34.

14 Ahmad Muhammad Abd. Ghaffar, Pengurusan Harta Pusaka, Wasiat, Hibah, Wakaf (Kuala Lumpur: Pustaka Syuhada, 2005), 3. 
hutang."

(Surah al-Nisa', 4: 12)

Manakala mirath dalam bahasa Arab adalah masdar (terbitan)

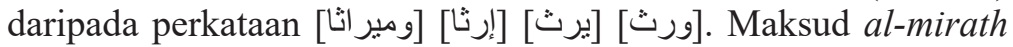
dari sudut bahasa ialah kekal, asal dan yang baki. Definisi mirath pada istilah ialah intiqal (perpindahan) atau memindahkan sesuatu, samada ianya berbentuk harta, ilmu atau kemuliaan dan kehormatan daripada seseorang kepada seseorang yang lain atau daripada satu kaum kepada kaum yang lain. ${ }^{15}$ Mirath juga boleh dimaksudkan sebagai pindahnya hak milik orang yang meninggal dunia kepada warisnya yang masih hidup, dan apa yang ditinggalkan itu sama ada harta alih atau harta tak alih atau hak-hak kepentingan yang tertentu menurut hukum syarak. Perpindahan ini berlaku disebabkan oleh wujudnya hubungan kerabat atau wala ${ }^{\prime}{ }^{16}$ Rasulullah SAW bersabda:

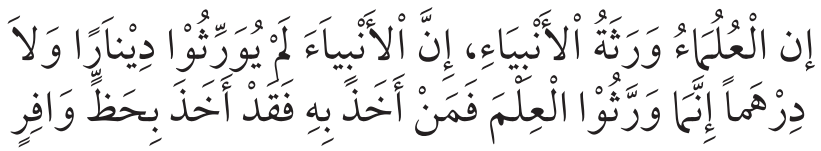

"Sesungguhnya ulama adalah pewaris para nabi, sesungguhnya para nabi tidak mewariskan dinar dan dirham, sesungguhnya mereka hanya mewariskan ilmu, maka barangsiapa yang mengambil warisan tersebut ia telah mengambil bahagian yang banyak." 17

Pengertian harta pusaka telah ditakrifkan dalam pelbagai sudut mengikut bidang. MenurutAli Muhammad al-Saibuni, harta pusaka

15 Mușțafā al-Bughā, al-Fiqh al-Manhajī 'alā Madhab al-Imām alShāfi 'ì (Dimashq: Dār-al-Qalam, 2000), 2: 275.

16 Muhammad 'Alī al-Șābūn̄i, al-Mawārīth fì al-Sharī' ah al-Islāmiyyah fi Daw'i al-Kitāb wa al-Sunnah, 34.

17 Al-Bukhārī, Șah̄ịh al-Bukhārī (Bayrūt: Dār al-Kutub al-'Ilmiyyah, t.t.), 1: 30. Terjemahan kitāb al-`Ilm, Bāb al-'Ilm Qabla al-Qawl wa al-'Amal. Lihat hadis riwayat Abu Daud, Kitab al-Ilm, Bab alHath ala Talab al-'Ilm, no. hadis 3641. Al-Bani menghukum hadis ini sahih. Syeikh al-Arna'out menghukum hadis ini sebagai hasan dengan syawahidnya. 
ialah seseuatu yang ditinggalkan oleh si mati daripada harta benda dan hak-hak yang akan diwarisi oleh waris disebabkan kematian pewaris. ${ }^{18}$ Definisi menurut undang-undang yang berkuatkuasa di Selangor, harta pusaka bermaksud harta yang di tinggalkan oleh simati dan boleh diwarisi oleh ahli keluarganya (ahli waris). Ia juga di sebut "harta warisan". Seksyen 2 Enakmen Wasiat Orang Islam (Selangor) $1993^{19}$ mentafsirkan harta pusaka ialah "termasuk harta alih dan tak alih, apa-apa manfaat dalam harta alih atau tak alih, hak, hak milik, tuntutan, hak dalam tindakan, samaada pada masa sekarang atau pada masa hadapan, atau yang selainnya mempunyai nilai menurut hukum syarak. "Harta Pusaka menurut undang-undang sivil dalam kamus Osborn's Concise Law Dictionary, ${ }^{20}$ ialah harta yang diperturunkan atau diwariskan daripada seseorang kepada seseorang ahli warisnya. Menurut P.H Collin di dalam kamusnya A Dictionary of Law ${ }^{21}$ mendefinisikan harta pusaka sebagai harta yang diterima oleh seseorang daripada orang yang telah meninggal dunia.

Harta pusaka juga dapat difahami sebagai nilai kebendaan yang ditinggalkan oleh si mati. Harta ini diperolehi melalui hasil jual beli, hadiah, sewaan atau hutang yang belum dijelaskan kepada si mati, dividen yang terbit daripada harta si mati, harta simpanan, atau harta yang terbit dari usaha si mati semasa hayatnya. Harta inilah yang menjadi harta pusaka yang ditinggalkan untuk waris si mati. Di sisi Islam, sekiranya harta ini dihibahkan, dijual atau diwakafkan oleh si mati semasa hayatnya, harta ini tidak termasuk sebagai harta pusaka. Contoh lain yang tidak termasuk dalam kategori harta pusaka ialah khairat kematian dan sedekah diberikan oleh orang yang menziarahi si mati. Begitu juga pampasan atau sagu hati daripada si mati kepada seseorang maka ia juga tidak dikira sebagai harta pusaka. Di sini dapatlah difahami bahawa, jika sesuatu nilai kebendaan khususnya harta yang wujud disebabkan kematian simati, maka harta tersebut tidak dikategori sebagai harta

18 Muhammad 'Alī al-Ṣābūn̄i, al-Mawārīth fì al-Sharī'ah al-Islāmiyyah fi Daw'i al-Kitāb wa al-Sunnah, 34.

19 Seksyen 2 EnakmenWasiat Orang Islam (Selangor) 1993.

20 P.G. Osborn, A Concise Law Dictionary for Students and Practitioners (London: Sweet \& Maxwell, 1927), 140.

21 P.H. Collin, A Dictionary of Law, ed. ke 4 (London: Bloomsbury, 2004), 154. 
pusaka. Namun jika si mati masih hidup dan akan tetap mendapat harta itu pada akhirnya, maka harta itu termasuk dalam kategori harta pusaka yang akan menjadi hak milik ahli waris yang berhak. Huraian ini tertakluk kepada Muslim seluruhnya termasuklah mualaf yang telah memeluk agama Islam.

Dalam membicarakan tentang harta pusaka, Allah SWT telah menerangkan secaraterperincimengenai pembahagian harta pusaka di dalam al-Quran. Aspek yang dijelaskan ialah bahagian setiap waris serta kedudukan mereka dalam mewarisi harta peninggalan si mati. Walau bagaimanapun, bahagian-bahagian yang telah ditetapkan kepada waris-waris adalah berbeza bergantung kepada jauh atau dekatnya hubungan waris-waris tersebut dengan si mati. Namun apabila berlaku kematian, pembahagian dan pengurusan harta pusaka merupakan satu perkara yang mesti dilaksanakan mengikut kaedah dan prosedur tertentu yang telah ditetapkan oleh syara' dan undang-undang. Kedua-duanya bergerak seiring.

Di Malaysia antara agensi yang terlibat dengan pengurusan harta pusaka adalah Mahkamah Tinggi Sivil, Unit Pembahagian Pusaka Kecil JKPTG, Amanah Raya Berhad (ARB), dan Mahkamah Syariah. Keempat-empat agensi ini mempunyai bidang kuasa dan tanggungjawab masing-masing dalam mengendalikan pengurusan harta pusaka. Mahkamah Tinggi Sivil mengendalikan kes harta pusaka orang Islam dan bukan Islam yang bernilai RM600,000.00 dan ke atas bagi yang memiliki harta alih sahaja dan juga bagi nilai harta RM2 juta ke atas yang melibatkan harta alih dan tak alih. Unit Pembahagian Pusaka Kecil menguruskan kes harta orang Islam dan bukan Islam bagi nilai harta RM2 juta dan ke bawah yang melibatkan harta alih dan tak alih dan harta bernilai RM600, 000. 00 ke bawah bagi harta tak alih sahaja. Manakala Amanah Raya Berhad mengendalikan kes bagi harta yang bernilai RM600,000.00 ribu dan ke bawah melibatkan harta alih sahaja yang melibatkan orang Islam dan bukan Islam.

Manakala Mahkamah Syariah mengendalikan kes berkaitan harta pusaka yang dimiliki oleh orang Islam sahaja melibatkan harta sepencarian, pengesahan wasiat, pengesahan hibah dan 
pengeluaran sijil faraid. ${ }^{22}$ Disamping itu, Mahkamah Syariah juga berbidang kuasa berkaitan pewarisan atau undang-undang harta untuk orang Islam merangkumi wasiat atau pengesahan semasa marad-al-maut seseorang si mati itu Islam, pengesahan hibah semasa hidup, atau penyelesaian yang dibuat tanpa balasan yang memadai dengan wang atau nilaian wang oleh seseorang orang Islam, pembahagian atau tuntutan harta sepencarian, pembahagian dan pewarisan harta berwasiat atau tak berwasiat dan penentuan orang-orang yang berhak kepada bahagian harta pusaka seseorang si mati Islam atau bahagian-bahagian yang kepadanya orangorang itu masing-masing berhak. ${ }^{23}$

Di sini, jelaslah bahawa dalam pengurusan harta pusaka di Malaysia, terdapat harta pusaka milik orang Islam dan harta pusaka milik bukan orang Islam. Islam mengiktiraf hak seseorang individu sama ada Islam atau bukan Islam untuk memiliki harta. Harta menjadi hak milik sempurna bagi mereka yang berusaha mendapatkannya dengan secara hak. Dalam konteks pindah milik harta, hukum Islam membenarkan pindah milik harta berlaku sama ada antara sesama Islam atau antara Islam dengan bukan Islam. Dalam hal ini, pindah milik atau keputusan untuk memindah milik harta itu mestilah berlaku semasa hidup. Justeru, muamalat jual beli, sewa-menyewa, pemberian, hadiah, wasiat adalah harus berlaku antara sesama Islam atau antara Islam dan bukan Islam. Bagaimanapun pindah milik atau muamalat harta yang berlaku selepas kematian, hukum Islam menyatakan bahawa harta hanya boleh dipindahmilik kepada waris yang beragama Islam sahaja kecuali terdapat wasiat. ${ }^{24}$

22 Norazura Sudin (Penolong Pengarah Kanan, Unit Pembahagian Pusaka Wilayah Persekutuan Kuala Lumpur), dalam temu bual beliau bersama penulis pada 24 Mei 2019.

23 Seksyen 46(2)(b)(iv), (v) dan (vi), Akta Pentadbiran Undang-Undang Islam (Wilayah-Wilayah Persekutuan) 1993 (Akta 505).

24 Jasni Sulong \& Amir Mohd Nason, "Saudara Baru dan Hak Kehartaan: Analisis daripada Perspektif Hukum Islam dan UndangUndang Semasa," Makalah, Seminar Kebangsaan Dakwah Saudara Kita: Isu dan Cabaran Semasa, Bahagian Pengajian Islam, Pusat Pengajian Ilmu Kemanusiaan, Universiti Sains Malaysia, 9-10 Oktober 2010). 
Rentetan daripada asimilasi antara anggota masyarakat yang semakin berkembang dan senario pertukaran daripada agama bukan Islam kepada agama Islam, konflik berhubung hak ke atas harta peninggalan waris yang berbeza agama juga turut terlibat. Maka kehadiran mualaf ialah satu rahmat besar terhadap perkembangan Islam yang seharusnya menjadi nilai tambah bukan sahaja terhadap kuantiti ummah malah juga terhadap kualiti ummah. Bagi seseorang yang baru memeluk agama Islam atau lebih dikenali sebagai mualaf, mereka turut tidak ditinggalkan dalam perbahasan agama. Melihat situasi pewarisan harta pusaka di Malaysia yang melibatkan mualaf, di sana terdapat sesuatu yang positif dan terdapat juga sesuatu yang negatif. Situasi ini memberi cabaran kepada mereka yang mengendalikan harta pusaka mualaf. Selain itu terdapat beberapa kelemahan yang digariskan melibatkan kelemahan dalam sistem pentadbiran harta pusaka di Malaysia. Antaranya alternatif faraid dikatakan bukanlah suatu penyelesaian harta yang tepat. Ini kerana kemungkinan terdapat fakta dikemukakan tidak tepat daripada ahli waris. ${ }^{25}$ Oleh demikian, untuk melihat kepada realiti sebenar isu, kes dan cabaran dalam pengurusan harta pusaka mualaf di Malaysia, maka pengkaji memilih untuk membuat kajian berkaitan pengurusan dan pentadbiran harta pusaka mualaf di Malaysia.

\section{PERUNTUKAN UNDANG-UNDANG DALAM PENTADBIRAN HARTA PUSAKA MUALAF DI MALAYSIA}

Sebelum Perang Dunia Kedua, pentadbiran dan pengurusan harta pusaka orang-orang Islam di Negeri-Negeri Melayu Tidak Bersekutu seperti Kelantan, Terengganu, Johor, Kedah dan Perlis dibawah tanggungjawab Jabatan Agama Islam Negeri (JAIN) atau Mahkamah Syariah negeri masing-masing. ${ }^{26}$ Selepas itu, pengurusan dan pentadbiran harta pusaka dikendalikan di peringkat persekutuan dan badan yang bertanggungjawab adalah Mahkamah Tinggi Sivil kerana urusan pembahagian harta pusaka, pewarisan berwasiat dan tidak berwasiat serta urusan mengeluarkan surat

\footnotetext{
25 Rusnadewi Abdul Rashid \& Noor Inayah Yaakub, "Masalah Kegagalan dan Kelewatan Pengagihan Harta Pusaka di Malaysia," 2. 26 Ibid.
} 
kuasa tadbir diletakkan di bawah senarai 1 Jadual Kesembilan, Senarai Persekutuan. Pentadbiran harta pusaka orang-orang Islam dan bukan Islam dikendalikan sepenuhnya oleh Pegawai penyelesai Pusaka, Perbadanan Amanah Raya Berhad atau Mahkamah Tinggi Sivil. ${ }^{27}$

Perkara yang berkaitan dengan harta pusaka ditadbir melalui beberapa peruntukan undang-undang sama ada undang-undang di peringkat persekutuan mahu pun di peringkat negeri. Peruntukan ini digubal bertujuan untuk memudahkan dan melancarkan perjalanan dalam mentadbir harta pusaka. Ringkasan kategori dan pembahagian undang-undang pentadbiran harta pusaka orang Islam, mualaf dan bukan Islam di Malaysia diringkaskan dalam graf 1 di bawah. Setiap daripada kategori tersebut diletakkan di bawah peruntukan undang-undang masing-masing.

Graf 1: Kategori Peruntukan Undang-Undang Pentadbiran Harta Pusaka

\begin{tabular}{|c|c|c|}
\hline \multicolumn{3}{|c|}{ Kategori Undang-Undang Pentadbiran Harta Pusaka } \\
\hline$\sqrt{ }$ & $\downarrow$ & $\downarrow$ \\
\hline $\begin{array}{c}\text { Orang Islam termasuk } \\
\text { mualaf }\end{array}$ & Bukan Islam & $\begin{array}{l}\text { Orang Islam \& Bukan } \\
\text { Islam }\end{array}$ \\
\hline $\begin{array}{l}\text {-Enakmen Pentadbiran } \\
\text { Agama Islam Negeri } \\
\text {-Enakmen Wasiat Orang } \\
\text { Islam Negeri }\end{array}$ & $\begin{array}{l}\text {-Akta Probet \& } \\
\text { Pentadbiran Pusaka } \\
1959\end{array}$ & $\begin{array}{l}\text {-Akta Probet \& } \\
\text { Pentadbiran } 1959 \text { (Akta } \\
97 \text { ) } \\
\text {-Akta Harta Pusaka } \\
\text { Kecil (Pembahagian) } \\
1955 \\
\text {-Akta Perbadanan } \\
\text { Amanah Raya } 1955 \\
\text { (Akta 532) }\end{array}$ \\
\hline
\end{tabular}

Sumber: Ilustrasi Penulis

Secara umumnya, pentadbiran harta pusaka di Malaysia sama ada melibatkan orang-orang Islam, mualaf atau bukan Islam

27 Mohd Zamro Muda, Mohd Ridzuan Awang, Abdul Basir Mohamad \& Md. Yazid Ahmad, Pengantar Undang-Undang dan Pentadbiran Pusaka, Wasiat dan Wakaf Orang Islam di Malaysia (Selangor: Jabatan Syariah, Fakulti Pengajian Islam, Universiti Kebangsaan Malaysia, 2008), 1. 
adalah terletak di bawah bidangkuasa eksklusif Persekutuan, dalam membuat undang-undang mengenainya sepertimana yang diperuntukkan di bawah Butiran 4 (e)(i) Senarai Persekutuan, Jadual Kesembilan. ${ }^{28}$ Perkara ini diletakkan di bawah bidangkuasa Mahkamah Sivil dan peruntukan mengenai harta pusaka itu merangkumi semua harta yang terdapat di peringkat persekutuan mahu pun di peringkat negeri tanpa mengira agama dan bangsa pemilik harta tersebut. Tidak dinafikan sebenarnya perundangan negeri melalui Butiran 1, Senarai II Senarai Negeri Jadual Kesembilan, memperuntukkan perkara yang sama, cuma yang membezakannya ialah Senarai Negeri memperuntukkan mengenai undang-undang, manakala Senarai Persekutuan memperuntukkan mengenai pentadbiran. Dari segi kedudukan dan taraf peruntukan itu sendiri, kedudukan Senarai Persekutuan mendapat kedudukan lebih tinggi dan mengatasi Senarai Negeri. ${ }^{29}$

\section{Peruntukan Undang-Undang berkaitan Pentadbiran bagi Orang Islam dan Mualaf}

Undang-undang berkaitan harta pusaka orang Islam termasuk mualaf adalah di bawah bidang kuasa negeri. ${ }^{30}$ Ketua bagi agama Islam adalah Sultan atau Raja bagi negeri masing-masing. ${ }^{31}$ Oleh itu, undang-undang berkaitan perkahwinan, perceraian dan ruju' serta pewarisan harta pusaka di bawah bidang kuasa negeri masingmasing perlu diluluskan di Dewan Undangan Negeri (DUN) bagi tujuan penggubalan dan pindaan serta terpakai kepada negeri terbabit sahaja. Undang-undang yang menguruskan pentadbiran orang Islam berkaitan harta pusaka warisan adalah Akta atau Enakmen Pentadbiran Agama Islam Negeri dan Enakmen Wasiat Orang Islam Negeri.

28 Rafidah Mohamad Cusairi@ Khushairi, "Isu-Isu Pengurusan Pembahagian Harta Pusaka Orang-orang Islam di Malaysia: Satu Kajian di Wilayah Persekutuan Kuala Lumpur," (Makalah, Seminar Penyelidikan Jangka Pendek (Vot F) 2003, 11 dan 12 Mac 2003).

29 Perkara 4 Perlembagaan Persekutuan, Bab 6.

30 Jadual 9, (Perkara 74,77) Senarai Perundangan, Senarai II, Senarai Negeri

31 Perkara 3. Perlembangaan Persekutuan, Bahagian I - Negeri-Negeri, Agama, dan Undang-Undang Bagi Persekutuan. Agama bagi Persekutuan. 


\section{Enakmen Pentadbiran Agama Islam Negeri}

Menerusi Enakmen Pentadbiran Agama Islam Negeri-Negeri, ${ }^{32}$ mahkamah mempunyai kuasa untuk memutuskan beberapa perkara yang berkaitan dengan harta seorang Islam terutamanya mengenai harta sepencarian, harta pusaka, hibah dan wakaf dan kadangkala dalam kes-kes tertentu fatwa mufti dirujuk bagi penentuan harta pusaka, status harta pusaka dan orang yang berhak terhadap harta itu. ${ }^{33}$ Sebagai contoh di Wilayah Persekutuan, undangundang yang melibatkan harta pewarisan adalah Akta Pentadbiran Undang-Undang Islam (Wilayah-Wilayah Persekutuan) 1993 (Akta 505) di bawah seksyen 50 terletak di bawah bidangkuasa Mahkamah Syariah. Dalam seksyen tersebut menyatakan, ${ }^{34}$

"Jika dalam perjalanan mana-mana prosiding yang berhubungan dengan pentadbiran atau pembahagian harta pusaka seseorang si mati Islam, mana-mana mahkamah atau pihak berkuasa, selain daripada Mahkamah Tinggi Syariah atau suatu Mahkamah Rendah Syariah, adalah mempunyai kewajipan untuk menentukan orang-orang yang berhak kepada bahagian dalam harta pusaka itu, atau bahagianbahagian yang kepadanya orang-orang itu masingmasingnya berhak, Mahkamah Syariah bolehlah, atas permohonan mana-mana orang yang menuntut bahawa dia menjadi benefisiari, atau wakilnya dan setelah dibayar olehnya fee yang ditetapkan, memperakukan fakta-fakta yang didapati olehnya dan pendapatnya mengenai orang-orang yang berhak kepada bahagian dalam harta pusaka itu dan mengenai bahagian-bahagian yang padanya mereka masing-masingnya berhak."

32 Perkara 13 (1) dan (2), Perlembagaan Persekutuan memberi jaminan hak individu untuk memiliki harta.

33 Mohd Zamro Muda, Mohd Ridzuan Awang, Abdul Basir Mohamad \& Md. Yazid Ahmad, Pengantar Undang-Undang dan Pentadbiran Pusaka, Wasiat dan Wakaf Orang Islam di Malaysia, 7.

34 Akta Pentadbiran Undang-Undang Islam (Wilayah-Wilayah Persekutuan). 1993 (Akta No. 505, 1993). 
Dalam Akta Pentadbiran Undang-Undang Islam (WilayahWilayah Persekutuan) 1993 menyatakan bidang kuasa Mahkamah Syariah dalam mengeluarkan sijil faraid iaitu bahagian yang berhak ke atas harta si mati yang beragama Islam ${ }^{35}$. Selain dari Wilayah Persekutuan, negeri Selangor juga mempunyai enakmen berkaitan pewarisan harta pusaka yang dikenali Enakmen Pentadbiran Agama Islam (Negeri Selangor) 2003 di mana dalam Enakmen Pentadbiran Agama Islam (Negeri Selangor) 2003 dalam perkara pewarisan menyatakan bahawa:

"Jika dalam perjalanan mana-mana prosiding yang berhubungan dengan pentadbiran atau pembahagian harta pusaka seseorang si mati yang beragama Islam, mana-mana mahkamah atau pihak berkuasa, selain Mahkamah Tinggi Syariah atau suatu Mahkamah Rendah Syariah mempunyai kewajipan untuk menentukan; orang-orang yang berhak mendapat bahagian dalam harta pusaka itu atau bahagian-bahagian yang kepadanya masingmasing orang itu berhak. " 36

Mahkamah Syariah boleh atas permohonan mana-mana orang yang menuntut bahawa dia menjadi benefisiari atau wakilnya, dan setelah dibayar olehnya fee yang ditetapkan, memperakui faktafakta yang didapati oleh Mahkamah Syariah itu dan pendapat Mahkamah Syariah itu tentang orang-orang yang berhak atau bahagian-bahagian itu. Dalam peruntukkan ini juga menyatakan bahawa mahkamah hanya boleh menentukan siapakah yang dikatakan sebagai ahli waris terhadap si mati tersebut. Bidang kuasa yang terdapat dalam peruntukkan ini jauh lebih terhad jika dibandingkan dengan bidangkuasa yang ada dalam institusi di peringkat persekutuan yang bukan sahaja dapat menentukan ahli waris bahkan boleh mentadbir harta pusaka tersebut. Dalam konteks ahli waris mualaf bukan beragama Islam, ahli waris tidak boleh menuntut harta pusaka mualaf di bawah Akta atau Enakmen Pentadbiran Agama Islam Negeri. Ini kerana di bawah akta ini, Mahkamah Tinggi Syariah atau Mahkamah Rendah Syariah

35 Akta Pentadbiran Undang-Undang Islam (Wilayah-Wilayah Persekutuan). 1993 (Akta No. 505, 1993).

36 Enakmen Pentadbiran Agama Islam (Negeri Selangor) 2003. 
membahagi harta pusaka dengan merujuk kepada undang-undang pusaka Islam iaitu faraid yang memperuntukkan harta hanya kepada si mati dan waris yang beragama Islam sahaja. ${ }^{37}$

\section{Enakmen Wasiat Orang Islam Negeri}

Penggubalan undang-undang orang Islam adalah dibawah kerajaan negeri. Maka kewujudan undang-undang untuk orang Islam bergantung kepada negeri masing-masing. Dalam undang-undang berkaitan wasiat, tidak semua negeri menggubal undang-undang ini. Hanya terdapat empat buah negeri yang telah menggubal dan meluluskan undang-undang wasiat Islam secara bertulis, iaitu Enakmen Wasiat Orang Islam (Negeri Selangor) 1999 (No.4, tahun 1999), Enakmen Wasiat Orang Islam (Negeri Sembilan) 2004 (No.5, tahun 2004), Enakmen Wasiat Orang Islam (Negeri Melaka) 2005 dan Enakmen Wasiat Orang Islam (Kelantan) 2009. Di Wilayah Persekutuan terdapat rang undang-undang Wasiat Orang Islam (Wilayah-wilayah Persekutuan) 2001, tetapi rang undang-undang ini masih belum diluluskan oleh Parlimen. Justeru itu, undang-undang ini sepatutnya dicontohi oleh negeri-negeri lain di Malaysia. Dari aspek peruntukan undang-undang berkaitan harta pusaka orang Islam dapat disimpulkan bahawa peruntukan peringkat negeri sangat sedikit dan sempit jika dibandingkan di peringkat persekutuan. Dalam konteks ahli waris kepada mualaf bukan beragama Islam pula, jika ahli waris tersebut membuat permohonan harta mualaf, maka permohonan tersebut akan diproses di bawah enakmen ini. Ini kerana dalam hukum syarak, orang Islam termasuk mualaf boleh mewasiatkan harta mereka kepada bukan Islam. Enakmen wasiat yang digubal dalam satusatu negeri akan dirujuk oleh Hakim Mahkamah Syariah dalam negeri tersebut dalam membuat keputusan. ${ }^{38}$

37 Mohd Khairy Kamarudin \& Azwan Abdullah, "Amalan Pembahagian Faraid di Malaysia," Journal of Global Business and Social Entrepreneurship 2, no. 3 (2016), 14.

38 Lihat Laman Web Rasmi My Government, Mengurus Institusi Keluarga dalam https://www.malaysia.gov.my/portal/ content/30319?language $=$ my , diakses pada 3 Oktober 2021 . 


\section{Peruntukan Pentadbiran Undang-Undang Harta Pusaka Melibatkan Orang Bukan Islam}

Peruntukan undang-undang harta pusaka melibatkan orang bukan Islam adalah di bawah Akta Probet dan Pentadbiran Pusaka 1959. Akta ini adalah salah satu akta yang digunapakai di Semenanjung Malaysia mula dikuatkuasa pada 1 Februari 1960. Akta ini berasal dari Ordinan 1959 (No. 35) yang disemak pada tahun 1972 dan dikeluarkan pada 26 Oktober 1972 sebagai undangundang melalui Akta No. 97 dan dikuatkuasa pada 1 November 1972. Akta ini diperuntukkan dan berfungsi sebagai cara-cara untuk mendapatkan surat kuasa probet (wasiat) atau Surat Kuasa Tadbir yang boleh dituntut atau di petisyen di Mahkamah Tinggi Sivil. Namun bagi kes orang-orang Islam yang melibatkan Harta Pusaka Besar atau Harta Pusaka Ringkas, Mahkamah Tinggi perlukan Sijil Faraid untuk menentukan kadar pembahagian pusaka kepada waris-waris yang berhak menurut hukum syarak. Terdapat tiga jenis surat kuasa wasiat dan surat kuasa tadbir di bawah bidangkuasa akta ini iaitu, ${ }^{39}$

a) Surat kuasa wasiat (probet) jika si mati meninggalkan wasiat yang meliputi semua hartanya (bagi si mati yang bukan beragama Islam).

b) Surat kuasa tadbir bagi harta pusaka tanpa wasiat.

c) Surat kuasa tadbir dengan wasiat berkembar apabila si mati meninggalkan wasiat untuk sebahagian daripada harta peninggalan dan sebahagian yang lain tanpa wasiat.

Bagi kes orang-orang Islam yang melibatkan Harta Pusaka Besar atau Harta Pusaka Ringkas, Mahkamah Tinggi perlukan Sijil Faraid untuk menentukan kadar pembahagian pusaka kepada waris-waris yang berhak menurut hukum syarak. Kadar pembahagian harta pusaka orang Islam dan penentuan waris samada berhak atau tidak akan diputuskan oleh Mahkamah

39 Mohd Zamro Muda, Mohd Ridzuan Awang, Abdul Basir Mohamad \& Md. Yazid Ahmad, Pengantar Undang-Undang dan Pentadbiran Pusaka, Wasiat dan Wakaf Orang Islam di Malaysia, 5 \&6. 
Syariah dan dikeluarkan dalam bentuk Sijil Faraid atau Perakuan Ahli Waris. ${ }^{40}$

\section{Peruntukan Pentadbiran Undang-Undang Harta Pusaka Melibatkan Orang Islam dan Bukan Islam}

Terdapat dua jenis akta di Malaysia yang memperuntukkan undang-undang harta pusaka kepada orang Islam dan bukan Islam sekaligus tanpa memisahkannya iaitu Akta Pusaka Harta Pusaka Kecil (Pembahagian) 1995 [Akta 98] dan Akta Perbadanan Amanah Raya 1995 [Akta 532].

\section{Akta Harta Pusaka Kecil (Pembahagian) 1955 [Akta 98]}

Akta ini digunakan di pejabat pusaka kecil, Jabatan Tanah dan Galian yang menjelaskan berkaitan proses dan pentadbiran dalam menguruskan harta pusaka.Akta Harta Pusaka Kecil(Pembahagian) 1955 dulu dikenali sebagai (Ordinan Pembahagian Pusaka Kecil 1955). Akta ini merupakan undang-undang utama yang dipakai dalam pengurusan pusaka kecil di Jabatan Ketua Pengarah Tanah dan Galian (Persekutuan) melalui Bahagian Pembahagian Pusaka/ Unit Pembahagian Pusaka ${ }^{41}$. Akta yang bersifat pentadbiran ini diluluskan bertujuan untuk menyelaras dan menyeragamkan caracara pembahagian dan pentadbiran pusaka si mati sama ada si mati beragama Islam atau bukan beragama Islam.

Di samping itu, akta ini di perkenalkan adalah bertujuan untuk menjimatkan perbelanjaan dan mempercepatkan proses pengendalian dan pengurusan sesuatu tuntutan pembahagian pusaka kecil. Secara tak langsung pembahagian bidangkuasa ini dapat membantu masyarakat di luar sana dalam menjimatkan kos

40 Rusnadewi Abdul Rashid \& Noor Inayah Yaakub, "Masalah Kegagalan dan Kelewatan Pengagihan Harta Pusaka di Malaysia," 2.

41 "Akta Harta Pusaka Kecil (Pembahagian) 1955". Laman sesawang Jabatan Ketua Pengarah Tanah dan Galian Persekutuan Kementerian Air, Tanah dan SumberAsli, dikemaskini pada 2 Ogos 2019, dicapai 5 Ogos 2019, https:/www.jkptg.gov.my/my/panduan/ senarai-undang-undang/akta-enakmen/akta-harta-pusaka-kecilpembahagian-1955 
dan masa ${ }^{42}$. Secara keseluruhannya akta ini menerangkan takrif pusaka kecil di samping menjelaskan bidangkuasa, proses kerja yang bermula dari permohonan pusaka, perbicaraan, pengeluaran perintah hinggalah proses rayuan ke mahkamah tinggi. Di samping akta, terdapat peraturan pembahagian pusaka yang menggariskan tatacara pelaksanaan dan pemakaian borang-borang dalam urusan penyelesaian pusaka kecil.

\section{Akta Perbadanan Amanah Raya 1995 [Akta 532]}

Akta Perbadanan Amanah Raya 1995 memberi kuasa kepada pihak Amanah Raya untuk mentadbir harta pusaka. Amanah Raya Berhad (ARB) adalah sebuah syarikat amanah yang ditubuhkan di bawah Akta Perbadanan Amanah Raya 1995 dikorporatkan di bawah Akta Syarikat 1965. Beroperasi sebagai sebuah syarikat pada 1 Ogos 1995. Sebelum itu, ARB merupakan sebuah jabatan kerajaan yang dikenali sebagai Jabatan Pemegang Amanah Raya. Amanah Raya mengeluarkan Surat Kuasa dalam bentuk Akuan atau Arahan seperti yang dilindungi oleh Akta Perbadanan Amanah Raya 1995. Di antara bidang kuasa ARB yang diperuntukkan:43

a) Mentadbir harta pusaka kecil si mati

b) Menjadi Pemegang Amanah biasa

c) Menjadi pemegang Amanah yang dilantik oleh Mahkamah Tinggi

\section{PENTADBIR HARTA PUSAKA DI MALAYSIA}

Kebanyakan masyarakat telah mengetahui institusi yang dipertanggungjawab untuk menguruskan harta pusaka. Walau bagaimanapun mereka masih kurang memahami tugas dan bidang kuasa institusi terlibat. Secara umumnya, urusan pentadbiran harta pusaka di Malaysia sama ada ianya terdiri daripada harta pusaka yang tidak berwasiat, harta pusaka yang berwasiat mahu pun harta pusaka separuh berwasiat telah diletakkan di bawah tanggungjawab empat buah institusi yang telah diiktiraf oleh

42 Mohd Zamro Muda, Mohd Ridzuan Awang, Abdul Basir Mohamad $\&$ Md. Yazid Ahmad, Pengantar Undang-Undang dan Pentadbiran Pusaka, Wasiat dan Wakaf Orang Islam di Malaysia, 4.

43 Seksyen 3 Akta Perbadanan Amanah Raya Berhad (Akta 352). 
kerajaan dan sah di sisi undang-undang di Malaysia. Institusiinstitusi yang dimaksudkan ialah terdiri daripada Mahkamah Tinggi Sivil, Mahkamah Tinggi Syariah, Amanah Raya Berhad, Jabatan Ketua Pengarah Tanah Dan Galian Persekutuan (JKPTG), seksyen pembahagian harta pusaka. ${ }^{44}$ Perbezaan fungsi antara agensi-agensi ini adalah dari segi fizikal atau jenis harta pusaka yang ditinggalkan oleh si mati dan bidang kuasa perundangan yang digunakan oleh agensi tersebut. Dari aspek fizikal atau jenis harta akan dilihat dari beberapa ciri berikut:

a) Harta pusaka berwasiat atau tidak berwasiat

b) Nilai harta yang ditinggalkan

c) Jenis harta sama ada harta alih atau tak alih atau gabungan kedua-duanya

\section{Mahkamah Tinggi Sivil}

Secara keseluruhannya, bidangkuasa Mahkamah Tinggi adalah melibatkan permohonan probet dan surat kuasa tadbir oleh waris atau wakil-wakil waris. Bidangkuasa yang diperuntukan kepada Mahkamah Tinggi adalah seperti berikut:

a) Mengikut Akta Harta Pusaka Kecil (Pembahagian) di bawah Seksyen 5 memperuntukkan bidangkuasa eksklusif Mahkamah Tinggi ke atas harta si mati yang berwasiat, dan juga kombinasi harta berwasiat dan tidak berwasiat. Walau bagaimanapun status wasiat yang melibatkan harta pusaka orang-orang Islam tidak boleh didengar di Mahkamah Tinggi, bahkan di bawah bidangkuasa Mahkamah Syariah.

b) Kuasa dalam mengeluarkan Surat KuasaWasiat atau Surat Kuasa Tadbir.

c) Mendengar dan membuat keputusan bagi kes rayuan apabila mana-mana pihak tidak berpuashati dengan perintah pembahagian yang dikeluarkan oleh Pentadbir Tanah ${ }^{45}$.

44 Nor Adila Mohd Noor, Che Zuina Ismail, Nor Azlina Mohd Noor \& Siti Mashitoh Mahamood, "Harta Wasiat Orang Islam: Satu Ulasan Ringkas dari Perspektif Perundangan di Malaysia," (e-Academia Special Issue TeMIC, Universiti Teknologi MARA Cawangan Terengganu, 2018), 40.

45 Seksyen 29(1), AktaPusaka Kecil (Pembahagian) 1955. 
d) Memutuskan perkara-perkara perundangan yang dirujuk oleh PegawaiTadbir Tanah ${ }^{46}$.

e) Membicarakan kes-kes yang dipindahkan kepadanya di bawah seksyen $8(7)$, iaitu permohonan bagi mendapat harta pusaka yang bernilai RM600,000.00 atau si mati meninggalkan wasiat tetapi permohonan awal telah dikemukakan di Pejabat Pembahagian Pusaka.

f) Memindahkan permohonan pentadbiran harta pusaka yang nilainya kurang RM600,000.00 kepada Pejabat Pembahagian Pusaka.

\section{Mahkamah Syariah}

Pengurusan dan pentadbiran harta pusaka orang Islam di Malaysia diagihkan kepada tiga agensi utama iaitu Mahkamah Tinggi, Seksyen Pembahagian Pusaka Kecil di bawah Pejabat Ketua Pengarah Tanah dan Galian dan Amanah Raya Berhad. Manakala Mahkamah Syariah hanya berperanan untuk mengeluarkan sijil faraid dan dirujuk apabila timbul isu-isu koleteral dalam pengurusan dan pentadbiran harta seperti isu keesahan perkahwinan, pengesahan ahli waris dan hak ahli waris ${ }^{47}$. Bidangkuasa Mahkamah Syariah dalam pentadbiran harta pusaka umat Islam di Malaysia ialah mengesahkan benefisiari (waris) yang berhak kepada harta pusaka si mati yang beragama Islam dan mengesahkan kadar bahagian benefisiari berkenaan.

Menurut Seksyen 50 Akta Pentadbiran Undang-Undang Islam (Wilayah-Wilayah Persekutuan) 1993 misalnya telah memperuntukkan bahawa Mahkamah Syariah berhak menentukan bahagian dan orang-orang yang berhak mendapat harta pusaka. Institusi yang berbidangkuasa diperingkatnegeri adalah Mahkamah Syariah. Walau bagaimanapun bidangkuasa Mahkamah Syariah sangat terhad tidak seluas bidangkuasa yang terdapat di peringkat persekutuan. Dalam Perlembagaan Persekutuan di bawah perkara 74(2), badan perundangan negeri boleh menggubal peruntukan

\footnotetext{
46 Seksyen 19(1)(i), AktaPusaka Kecil (Pembahagian) 1955.

47 Suhaimi Ab Rahman, Rasyikah Md Khalid, Adilah Abd Razak \& Abu Bakar Jaafar, "Pemerkasaan Mahkamah Syariah dalam Pentadbiran Harta Pusaka Masyarakat Islam menurut Kerangka Federalisme di Malaysia," Akademika 88, no. 3 (2018), 113-125, 113.
} 
mengenai sesuatu perkara yang terdapat dalam senarai negeri dan juga senarai Bersama Perlembagaan Persekutuan ${ }^{48}$. Kedudukan bidangkuasa bagi kerajaan negeri diperuntukkan melalui Jadual Kesembilan, Senarai II - Senarai Negeri Perlembagaan Persekutuan iaitu “...termasuk hokum syarak berhubung dengan mewarisi harta berwasiat dan takberwasiat...." Berdasarkan kepada peruntukan di atas maka dapat dinyatakan bahawa kerajaan negeri juga mempunyai bidangkuasa dalam soal harta pusaka.

\section{Unit Pembahagian Pusaka Kecil}

Seksyen Pembahagian Pusaka Kecil di bawah Pejabat Ketua Pengarah Tanah dan Galian salah satu agensi utama yang diberi kuasa mengurus dan mentadbir harta pusaka orang Islam dan bukan Islam. Mengikut Akta Harta Pusaka Kecil (Pembahagian) 1955, Pejabat Pembahagian Pusaka telah diberi kuasa dalam menguruskan harta pusaka terutamanya harta pusaka kategori pusaka kecil. Dari segi pelaksanaan yang kehendak perundangan, pegawai yang mengendalikan pembahagian harta pusaka kecil diwartakan sebagai:

a) Penolong Pentadbir Tanah bagi tiap-tiap negeri mengikutseksyen 12(1)(b) Kanun Tanah Negara 1965 dan tertakluk kepada pengawasan Pengarah Tanah dan Galian Negeri. Dengan itu, pegawai pusaka kecil akan membicarakan kes atas kapasiti sebagai pentadbir tanah dan mengeluarkan perintah atas kapasiti yang sama.

b) Bertindak sebagai Majistret kelas dua mengikut seksyen 79 Akta Mahkamah-Mahkamah Rendah 1948 bagi tujuan pengendalian bersumpah dan untuk memudahkan waris-waris bagi membuat dan mengemukakan Surat Akuan Sumpah mengikut Akta Akuan Sumpah 1960.

Dalam menjalankan kuasa, agensi ini hanya berbidangkuasa bagi nilai harta yang kurang daripada RM600,000.00 yang terdiri dari harta tak alih. Sekiranya terdapat harta alih dan tak alih yang nilainya bawah RM2,000,000.00 juga akan diuruskan oleh agensi ini.

48 Perkara 74(2) Perlembagaan Persekutuan. 


\section{Amanah Raya Berhad}

Amanah Raya Berhad diberi kuasa untuk mentadbir semua jenis harta pusaka sama ada harta pusaka kecil, harta pusaka ringkas, harta pusaka biasa dan boleh secara terus mentadbir harta alih si mati berlandaskan mengikut hukum faraid bagi orang Islam atau Akta Pembahagian 1958 bagi yang bukan beragama Islam. Bidang kuasa Amanah Raya Berhad dalam pengurusan harta pusaka berdasarkan undang-undang yang telah diperuntukkan dalam urus tadbir harta. Ia tertakluk kepada undang-undang seperti Akta Perbadanan Amanah Raya 1995 (Akta 532), Akta Pemegang Amanah 1949 (Akta 208), Akta Probet dan Pentadbiran 1959 (Akta 97), Akta Pembahagian 1958 (Akta 300) dan Akta Wasiat 1959 (Akta 346). Peranan Amanah Raya Berhad sebagai pemegang saham adalah meneliti harta, liabiliti, dan mengenal pasti penghutang dan pemiutang si mati, juga melunaskan hutang si mati, mengeluarkan surat kuasa dalam bentuk Akuan berdasarkan seksyen 17(1) Akta 532 dan Surat Kuasa dalam bentuk Arahan berdasarkan 17(2) Akta 532. Dan satu lagi peranannya sebagai pengagih harta pusaka. ${ }^{49}$

Selain itu di bawah Seksyen 17 (1) Akta Perbadanan Amanah Raya 1995, Amanah Raya boleh mengeluarkan Surat Kuasa dalam bentuk Akuan dengan perincian aset bagi harta alih bernilai tidak lebih RM600 ribu. Akuan ini tertakluk kepada faraid bagi orang Islam dan Akta Pembahagian 1958 bagi orang bukan Islam atau tertakluk kepada persetujuan semua waris seperti ditetapkan. Manakala di bawah Seksyen 17 (2) Akta Perbadanan Amanah Raya 1995, Amanah Raya boleh mengeluarkan Surat Kuasa bagi harta alih RM50 ribu dan ke bawah. Namun waris perlu mengemukakan arahan tersebut kepada pihak bank untuk menerima bayaran. ${ }^{50}$ Harta Pusaka yang ditadbir di bawah Amanah Raya Berhad merangkumi aset-aset seperti hartanah, harta benda dan pelaburan

49 Ainan Husnaa Muhammad Saifullah \& Siti Mashitoh Mahamood, "Isu-Isu Berbangkit dalam Pengurusan Harta Pusaka Ringkas secara Berwasiat dan Tidak Berwasiat di Amanah Raya Berhad (ARB)," Journal of Shariah Law Research 5, no. 2 (2020), 207-230.

50 Artikel Mustapha Yanoorhady Zalifah dalam https://www. amanahraya.my/wp-content/uploads/2020/12/Artikel_Mustapha Yanoorhady_Zalifah_-271120-1.pdf diakses pada 3 Oktober 2021 
yang ditinggalkan oleh simati. Mentadbir Pusaka boleh memakan masa selama 3 bulan atau bertahun-tahun bergantung kepada jenis aset dan sebarang pertikaian yang mungkin timbul. Justeru itu, pemilihan pentadbir seperti Amanah Raya Berhad sangat penting dalam menguruskan dan mentadbir Pusaka simati. ${ }^{51}$

\section{KESIMPULAN}

Di Malaysia, terdapat peruntukan undang-undang bagi harta pusaka tinggalan si mati kepada waris samada Islam atau bukan Islam. Asasnya peruntukan undang-undang ini berdasarkan kategori harta yang dibahagikan kepada tiga bahagian, iaitu harta pusaka biasa, harta pusaka kecil dan harta pusaka ringkas. Berdasarkan kepada kategori-kategori tersebut, pihak perundangan persekutuan telah menggubal beberapa akta bagi mentadbir perkara tersebut.

Secara umumnya, bagi Muslim, ahli waris boleh merujuk Enakmen Pentadbiran Agama Islam Negeri atau Enakmen Wasiat Orang Islam Negeri bagi urusan harta pusaka si mati yang Muslim (kategori harta pusaka biasa dan kecil). Manakala bagi bukan Muslim, ahli waris perlu merujuk Akta Probet dan Pentadbiran Pusaka 1959. Tetapi akta ini turut terpakai kepada Muslim dan bukan Muslim termasuk Akta Harta Pusaka Kecil (Pembahagian) 1955 dan Akta Perbadanan Amanah Raya 1955 (Akta 532).

Berdasarkan penetapan undang-undang pula, harta pusaka biasa yang jumlah nilainya RM600,000.00 ke atas samada ianya terdiri daripada harta alih kesemuanya atau campuran antara harta tak alih dengan harta alih adalah tertakluk di bawah Akta Probet dan Pentadbiran Pusaka 1959. Manakala bagi jumlah kurang daripada RM600,000 maka harta pusaka dan pembahagiannya di bawah Akta Harta Pusaka Kecil (Pembahagian) 1955 (Akta 98). Keduadua akta ini terpakai kepada Muslim atau bukan Muslim. Dengan wujudnya Akta Harta Pusaka Kecil (Pembahagian) 1955 (Akta 98) ini memudahkan, mengurangkan kos dan mempercepatkan proses tuntutan harta pusaka kecil. Sebaliknya bagi harta pusaka

51 Laman Web Rasmi Amanah Raya, Pentadbiran Pusaka. Lihat https:// www.amanahraya.my/ms/pentadbiran-pusaka/ diakses pada 3 Oktober 2021. 
ringkas pula tertakluk di bawah Akta Perbadanan Amanah Raya Berhad 1995 (Akta 532).

Menyentuh pewarisan harta pusaka Islam dan bukan Islam, semuanya kembali kepada si mati. Jika si mati beragama Islam maka ahli waris perlu merujuk undang-undang pusaka Islam iaitu faraid. Ini bermakna ahli waris perlu merujuk Mahkamah Syariah sebagai pentadbir. Jika si mati bukan beragama Islam maka ahli waris perlu merujuk Mahkamah Sivil. Amalan di Malaysia, Mahkamah Syariah mengendalikan kes-kes orang Islam dan pembahagian harta adalah menerusi faraid. Maka jelas bahawa ahli waris bukan Islam tidak layak menerima harta pusaka si mati yang Muslim. Manakala jika si mati bukan beragama Islam maka di bawah Akta Pembahagian 1958, ahli waris samada Islam atau bukan Islam mewarisi harta si mati yang bukan Islam. Walaupun ini bertentangan dengan hukum Islam, namun undang-undang sivil di Malaysia meraikan pemberian harta pusaka bukan berdasarkan agama, sebaliknya berdasarkan pertalian kekeluargaan. Konflik ini sehingga kini masih berterusan dan tiada lagi penyelesaian mutlak.

\section{RUJUKAN}

Abū 'Abd Allāh Muḥammad bin Ismā'īl al-Bukhārī. 2008. Șahịḥ al-Bukhārī dalam Mawsū'at al-Hadīth al-Sharīf: al-Kutub al-Sittah. Șālih bin 'Abd al-'Azīz Āl al-Shaykh (ed.). Riyadh: Dār al-Salām.

Ahmad Muhammad Abd. Ghaffar. Pengurusan Harta Pusaka, Wasiat, Hibah, Wakaf. Kuala Lumpur: Pustaka Syuhada, 2005.

Ainan Husnaa Muhammad Saifullah \& Siti Mashitoh Mahamood, "Isu-Isu Berbangkit dalam Pengurusan Harta Pusaka Ringkas secara Berwasiat dan Tidak Berwasiat di Amanah Raya Berhad (ARB)," Journal of Shariah Law Research 5, no. 2 (2020), 207-230.

Al-Baghawī, Abū Muhammad al-Husayn bin Mas'ūd. al-Tahzị̄b fì Fiqh al-Imām al-Shāfi ‘ì. Bayrūt: Dār al-Kutub al-'Ilmiyyah, t.t.

Al-Bukhārī. Șah̄ih al-Bukhārī. Bayrūt: Dār al-Kutub al-'Ilmiyyah, t.t. 
Elviana Sagala. "Ketentuan Tentang Harta Peninggalan (Tarikah) dalam Hukum Islam." Jurnal Ilmiah "Advokasi” 5, no. 1 (2017).

Jasni Sulong \& Amir Mohd Nason. "Saudara Baru dan Hak Kehartaan: Analisis daripada Perspektif Hukum Islam dan Undang-Undang Semasa," Makalah, Seminar Kebangsaan Dakwah Saudara Kita: Isu dan Cabaran Semasa, Bahagian Pengajian Islam, Pusat Pengajian Ilmu Kemanusiaan, Universiti Sains Malaysia, 9-10 Oktober 2010.

M. Abdul Mujieb. Kamus Istilah Fiqh. Jakarta: PT Pustaka Firdaus, 1997.

Mohd Khairy Kamarudin \& Azwan Abdullah, "Amalan Pembahagian Faraid di Malaysia," Journal of Global Business and Social Entrepreneurship 2, no. 3 (2016), 14

Mohd Zamro bin Muda \& Md Yazid bin Ahmad. 2001."Pewarisan Muslim dan Non-Muslim Menurut Undang-Undang di Malaysia: Kajian Perbandingan", (Makalah, Seminar Kebangsaan Undang-Undang Perbandingan, Jabatan Syariah, Fakulti Pengajian Islam, Universiti Kebangsaan Malaysia, 12-13 Jun 2001).

Mohd Zamro Muda, Mohd Ridzuan Awang, Abdul Basir Mohamad \& Md. Yazid Ahmad. Pengantar Undang-Undang dan Pentadbiran Pusaka, Wasiat dan Wakaf Orang Islam di Malaysia. Selangor: Jabatan Syariah, Fakulti Pengajian Islam, Universiti Kebangsaan Malaysia, 2008.

Muhammad 'Alī al-Ṣābūnī. al-Mawārīth fì al-Sharī'ah alIslāmiyyah fì Daw'i al-Kitāb wa al-Sunnah. Dimashq: Dār al-Qalam, 1989.

Muștafā al-Bughā. al-Fiqh al-Manhaj̄̄ 'alā Madhab al-Imām alShäfi ‘i. Dimashq: Dār-al-Qalam, 2000.

Noor Syahida Abdul Rahman, Hasliza Talib, Nurhayati Abd. Ghani, Nur Zulfah Md Abdul Salam \& Nurul Syafini Abd Rahman. "Pengurusan Tuntutan Harta Pusaka dalam Kalangan Masyarakat Islam: Kajian di Lembah Klang." Journal of Muwafaqat 1, no. 2 (2018), 96-117. 
Nor Adila Mohd Noor, Che Zuina Ismail, Nor Azlina Mohd Noor \& Siti Mashitoh Mahamood. "Harta Wasiat Orang Islam: Satu Ulasan Ringkas dari Perspektif Perundangan di Malaysia." e-Academia Special Issue TeMIC, Universiti Teknologi MARA Cawangan Terengganu, 2018.

Noresah Bahrom et al. Kamus Dewan, ed. 4. Kuala Lumpur: Dewan Bahasa dan Pustaka, 2005.

Noresah Bahrom et al., Kamus Dewan, ed 3, cet. ke 2. Kuala Lumpur: Dewan Bahasa dan Pustaka, 1996.

Nurul Izzah Nokman \& Farahwahida Mohd Yusof. "Perspektif Masyarakat Muslim Terhadap Pengurusan Harta Pusaka di Kuala Terengganu.” Disertasi Sarjana, Universiti Teknologi Malaysia, 2012.

P.G. Osborn. A Concise Law Dictionary for Students and Practitioners. London: Sweet \& Maxwell, 1927.

P.H. Collin. A Dictionary of Law, ed. ke 4. London: Bloomsbury, 2004.

Rafidah Mohamad Cusairi@ Khushairi. "Isu-Isu Pengurusan Pembahagian Harta Pusaka Orang-orang Islam di Malaysia: Satu Kajian di Wilayah Persekutuan Kuala Lumpur." Makalah, Seminar Penyelidikan Jangka Pendek (Vot F) 2003, 11 dan 12 Mac 2003.

Rusnadewi Abdul Rashid \& Noor Inayah Yaakub, "Masalah Kegagalan dan Kelewatan Pengagihan Harta Pusaka di Malaysia," Jurnal Intelek 5, no. 2 (2010).

Siti Adibah Abu Bakar \& Siti Zubaidah Ismail. "Pengurusan Mualaf di Malaysia: Kerjasama Dinamik Antara Agensi Kerajaan dan Bukan Kerajaan." Jurnal Usuluddin 46, no. 2 (2018), 98.

Suhaimi Ab Rahman, Rasyikah Md Khalid, Adilah Abd Razak \& Abu Bakar Jaafar. "Pemerkasaan Mahkamah Syariah dalam Pentadbiran Harta Pusaka Masyarakat Islam menurut Kerangka Federalisme di Malaysia." Akademika 88, no. 3 (2018), 113-125. 


\section{Statut}

Akta Pentadbiran Undang-Undang Islam (Wilayah-Wilayah Persekutuan). 1993 (Akta No. 505, 1993).

Akta Pentadbiran Undang-Undang Islam (Wilayah-Wilayah Persekutuan) 1993 (Akta 505).

Akta Perbadanan Amanah Raya Berhad (Akta 352).

Akta Pusaka Kecil (Pembahagian) 1955.

Enakmen Pentadbiran Agama Islam (Selangor) 2003.

Enakmen Wasiat Orang Islam (Selangor) 1993.

Perlembagaan Persekutuan.

\section{Temu bual}

Nazli Zainal (Ketua Penolong Pengarah, Unit Pembahagian Pusaka Wilayah Persekutuan Kuala Lumpur), dalam temu bual beliau bersama penulis pada 27 Jun 2019.

Norazura Sudin (Penolong Pengarah Kanan, Unit Pembahagian Pusaka Wilayah Persekutuan Kuala Lumpur), dalam temu bual beliau bersama penulis pada 24 Mei 2019. 
Jurnal Fiqh, Vol. 18 No. 2 (2021) 315-344 